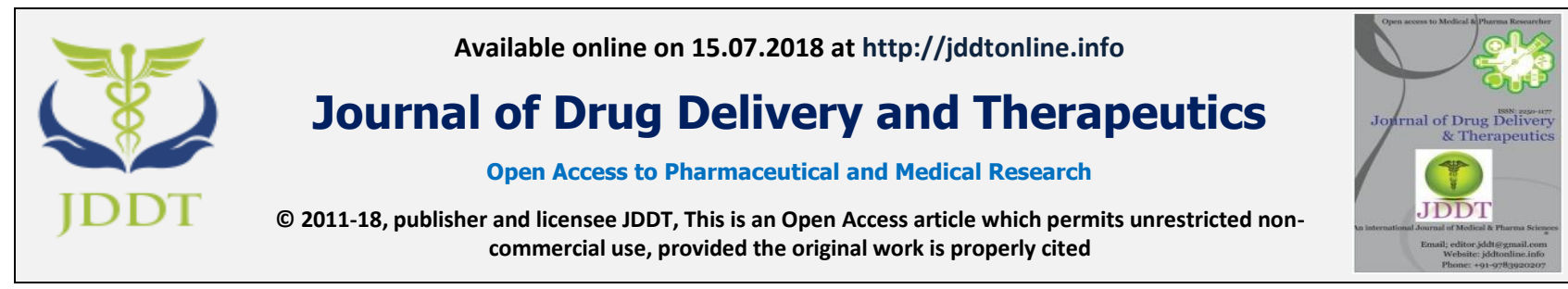

Open $\odot$ Access

Review Article

\title{
A REVIEW ON PHYTOCHEMICAL AND PHARMACOLOGICAL PROPERTIES OF THESPESIA POPULNEA
}

\author{
CH. Malathi Suvarna,* P. Sriya, MD. Arshad, K. Pavan \\ Department of Pharmacology, Gland Institute of Pharmaceutical Sciences, Narsapur, Medak District, Telangana, India
}

\begin{abstract}
Most of the drugs available today are directly or indirectly derived from plants. The objective of present review is to provide advance information including traditional uses, phyotochemical, Pharmacognostic and pharmacological of Thespesia populnea for easy access of researchers intending to work on the wide range of active chemical constituents in this plant. A fast growing ever green shrub native to saline, sandy, volcanic, limestone and rocky soils especially in tropical and subtropical areas could be seen anywhere and easy to propagate and grow. Its activity spectrum ranges from memory enhancing to cytotoxic to immunmodulatory to antidiuretic. Here we discussed the latest development in the activities of different parts of the plant T. populnea.
\end{abstract}

Keywords: Pharmacological activity, Phytochemical screening, Ethnomedicine, Thespesia populnea.

Article Info: Received 02 Feb, 2018; Review Completed 07 May 2018; Accepted 21 May 2018; Available online 15 July 2018

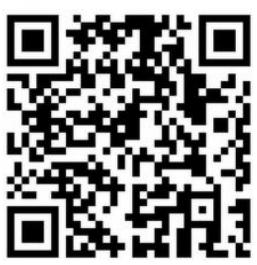

\section{Cite this article as:}

Suvarna CHM, Sriya P, Arshad MD, Pavan K, A review on phytochemical and pharmacological properties of Thespesia populnea, Journal of Drug Delivery and Therapeutics. 2018; 8(4):1-4 DOI: http://dx.doi.org/10.22270/jddt.v8i4.1718

*Address for Correspondence:

Ch, Malathi Suvarna, HIG - 86, Balaji Nagar, Kukatpally, Hyderabad, Telangana, 500072, India

\section{INTRODUCTION}

Thespesia populnea belonging to Malvaceae family is a fast growing evergreen shrubby tree reaching to a height of 30-50 feet with a width of around 10-20 feet. It is commonly known as Portia tree. It is a perennial tree growing throughout the year. It propagates easily and grows rapidly. The propagation is through seeds or stem cuttings. It grows well along warm coastal areas near the mangroves and is valuable as a coastal windbreak because it is highly resistant to salt spray, sea wind, brackish water, heat and drought. It grows well in sandy and saline soils; it can also grow on volcanic, limestone and rocky soils ${ }^{1}$. It is considered as indigenous to Pacific islands however some authors reveal that it may have been brought by early Polynesians. It is currently naturalized in tropical and subtropical climates throughout the world especially in Central America, Asia, Caribbean islands, Indonesia, Philippines, Indian and Pacific Ocean islands.

It has a short, straight or crooked trunk with crowded lower horizontal branches. The bark is brown or pale grey with deep fissures and ridges. The leaves are simple with entire margin and are arranged alternately. The leaf is glossy green color above and pale green below. Leaf blades are heart shaped, leaf stalks are long, leaf apex is acuminate and base is cordate ${ }^{2}$. Flowers are typical hibiscus shape in appearance, $4-7 \mathrm{~cm}$ in length, with five overlapping, broad rounded petals. Color is pale yellow with maroon spot at the base of each petal and with star shaped hairs on outer surface. Flowers open and close on the same day and the yellow flowers turn dark red, purple or pink as the day progresses. Fruits are brittle, dry, woody or papery. They are pods with seed capsules rounded and flattened containing five cells and several seeds. The brown hairy seeds are about $1 \mathrm{~cm}$ long and $0.6 \mathrm{~cm}$ broad $^{3}$. Seeds are blown short distances by wind but more likely to be dispersed by the water (ocean currents). Both the light weight fruits and seeds can float from one island to another on ocean currents ${ }^{4}$.

\section{ETHNOMEDICINAL USES}

The ethno medicinal uses of the plant Thespesia populnea suggested vital role in the treatment of various 
diseases. In the indigenous system of medicine the paste of leaves, fruits and roots of T.populnea is applied locally for their anti inflammatory effects. The yellow juice of fruits is employed in treating insect bites, migraine, headache, fistula, psoriasis, scabies, tinea and warts. The bark, leaves, flowers and fruits are reported to be useful in various skin infections. The seeds possess purgative properties. Bark is used in haemorrhoids and chronic dysentery. Flowers are used in itching. The extract from peduncles is used to treat centipede stings. The wood is used to treat cholera and pleurisy. A decoction of bark is given internally in diseases of skin and that of fruits as an antidote for poisoning. The compound oil of bark and capsule is useful in arthritis and gonorrhea ${ }^{5,6}$.

\section{PHYTOCHEMICAL STUIDES}

The major phyto constituents reported in T. populnea include Anthraquinone glycosides, cardiac glycosides, flavonoids, alkaloids and tannins. Gossypol was found to be a major constituent producing anti inflammatory effect in as well as human beings. Air dried flowers of T.populnea contain kaempferol, $\beta$-sitosterol, gossyptein and a mixture of Kaempferol 3-glucoside, Quercetin 3glucoside, Kaempferol 5-glucoside separated, Rutin, Kaempferol 3-rutinoside and Kaempferol 7-glucoside ${ }^{7}$. A Dextro-rotatory gossypol has recently been isolated from flowers, fruits and bark. The gossypol content in different parts of the tree are seed(3.14\%), flower buds(3.37\%), leaves(1.66\%), $\operatorname{roots}(2.11 \%)$, stem $(1.43 \%)$. Presence of Herbecetin and thespesin has been reported from fruits ${ }^{8}$.

Heartwood is reported to contain Sesquiterpenoids, named Populene A-H (1-8) ${ }^{9}$. It also contains 6 Sesquiterpenoidal quinones of the mansonone group containing the cadalene skeleton. Four were identified as Mansonone C, D, E, and F. The other 2 are new natural products belonging to this group and are named thespesone I and thespone II. Based on spectral studies and chemical properties, their structures are assigned as 1,2,6,9-Tetrahydro-7-hydroxy-1,5,8-trimethylnaphtho[2, 1-b]furan-6, 9-dione and 6,7-Dihydro-1,5,8trimethylnaphtho[2, 1-b]furan-6,7-dione, respectively. Mansonone-D has been converted into both thespesone and thespone under oxidation conditions 9. A new Mansonone, 7 Hydroxy- 2,3,5,6 -tetrahydro -3,6,9trimethylnaphtho [1,8-b,c]pyran-4,8-dione, in addition to mansonone D, E and F were isolated from the heartwood of $T$. populnea. ${ }^{10}$

A new sesquiterpenequinone Thespesenone and Dehydrooxoperezinone-6-methyl Ether were isolated from $T$. populnea ${ }^{11}$. Stem bark contains alkaloids, carbohydrates, protein, tannins, phenols, flavonoids, gums and mucilage, saponins and terpenes ${ }^{[12]}$ of $T$. populnea are reported to contain $\beta$-Sitosterol-3-O- $\beta$-Dglucopyranoside-6'-O-stearate, $\quad \beta$ - $\quad$ Sitosterol, Daucosterol, Kaempferol, 1-Hentriacontanol, Stearic acid, Betulin ${ }^{13}$. Leaves of T. populnea contain Lupeol, $\beta$ - Sitosterol as the major constituents it also contain presence of Pupenone, Alkanes. ${ }^{14,15}$

\section{PHARMACOLOGICAL ACTIVITIES}

\section{Anti inflammatory, Analgesic:}

The ethanolic extract of T.populnea bark was investigated for its potential as an anti inflammatory and analgesic at doses of 100, 200 and $400 \mathrm{mg} / \mathrm{kg}$ body weight. The anti inflammatory activities were evaluated by both acute and chronic models. The higher doses were inhibiting carrageenan, histamine and serotonin induced paw edema as well as formaldehyde induced paw edema successfully. The acetic acid induced writhing response and formalin induced paw licking time in early and late phases of mice were used to assess analgesic activity. The result indicates that TPE (200 and $400 \mathrm{mg} / \mathrm{kg}$ p.o.) and indomethacin could protect against the carrageenan induced acute inflammation. The treatment with TPE (200 and $400 \mathrm{mg} / \mathrm{kg}$ p.o.) produced a significant and dose dependent inhibition in abdominal writhes produced by acetic acid. ${ }^{16}$

\section{Anti diarrheal:}

From the aqueous extract fractions namely methanolic fraction (MF) and residue fraction (RF) were made and studied for anti-diarrheal activity in castor oil induced diarrhea model, the RF and MF has significantly reduced the cumulative wet fecal mass, where as the, RF was found to be more potent than MF. RF had shown significant inhibition of PG- $\mathrm{E}_{2}$ induced secretions (antisecretary) and decreased the movement of charcoal in charcoal meal test indicating its anti-motility activity. Furthermore, RF has showed significant inhibition of acetylcholine, histamine and $\mathrm{BaCl}_{2}$ induced contractions on rat colon, guinea pig ileum and rabbit jejunum with $\mathrm{EC}_{50}$ values of $241.7,303.1$ and $286.1 \mu \mathrm{g} / \mathrm{mL}$, respectively indicating the anti-motility effect of RF. The phytochemical analysis of RF showed presence of gums and mucilage and the possible mechanism may be the combination inhibition of elevated prostaglandin biosynthesis and reduced propulsive movement of the intestine. $^{17}$

\section{Hepatoprotective:}

Leaf, flower and stem bark of $T$. populnea showed varying levels of protective action against $\mathrm{CCl}_{4}$-induced liver damage as evidenced from significant reduction in the activities of serum marker enzymes for liver damage (alanine transaminase, aspartate transaminase, and alkaline phosphatase), and bilirubin levels when compared with $\mathrm{CCl}_{4}$-intoxicated control rats. The stem bark suspension showed maximum hepatoprotection compared with leaf and flower. An ethanol extract of the stem bark was more active than n-hexane and water extracts, the hepatoprotective effect of this extract was almost comparable to that of silymarin $(100 \mathrm{mg} / \mathrm{kg})$, a reference herbal drug. 18

T. populnea (Malvaceae) bark was extracted with methanol and water. The extracts were vacuum dried to yield the respective Methanolic (MET) and Aqueous extract (AET). The extracts were evaluated for hepatoprotective activity against Carbon Tetrachloride $\left(\mathrm{CCl}_{4}\right)$ induced liver damage at 2 dose levels (250 and $500 \mathrm{mg} / \mathrm{kg}$ ). The biochemical parameters observed in serum were Total Bilirubin, Alkaloid Phosphatase 
(ALP), Serum Glutamate Oxaloacetate Transaminase (SGOT), Serum Glutamate Pyruvate Transaminase (SGPT) levels and Total Protein. Aspartate Transaminase (AST), Alanine Transaminase (ALT) and Total Protein levels in liver were also evaluated. Histopathologic study on the liver tissue was also performed. The extracts exhibited dose dependent reduction in Total Bilirubin, ALP, SGOT, SGPT, AST, ALT and increase in total protein (serum and liver) levels. The extracts also exhibited only mild hepatocytic damage compared to the $\mathrm{CCl}_{4}$ treated group. MET was found to exhibit higher hepatoprotection than AET. ${ }^{19}$

\section{Anti implantation activity:}

A preliminary study reveals that the active principles from Petroleum Ether (PE) and Ethyl Acetate (EAc) extracts of T.populnea showed anti implantation activity. Graded doses of the active principles and the crude alcoholic extract (in $1 \%$ gum acacia suspension) were taken and tested in Sprague-Dawley female rats of normal estrus cycle after overnight cohabitation with males of proven fertility. The day when spermatozoa were detected in vaginal smear was treated as 1 st day of pregnancy. The compounds were administered to female rats from the 1 st day to the 7 th day of pregnancy. On the 10th day, the rats were laparotomized under light anesthesia and the numbers of implantation sites and corpora lutea were noted. Results showed significant anti implantation activity and they were found to be a mixture of two groups of long-chain fatty acids from GLC. ${ }^{20}$

\section{Anti oxidant activity:}

Antioxidant activity of the AET and MET of the $T$. populnea bark was investigated in rats by inducing liver injury with carbon tetrachloride: olive oil (1:1). The extracts exhibited significant antioxidant activity showing increased levels of Glutathione Peroxidase, Glutathione S- Transferase (GST), Glutathione Reductase (GRD), Superoxide Dismutase (SOD) and Catalase (CAT) and decreased level of Lipid peroxidation (LPO). T. populnea bark extracts, AET and MET, at a dose level of $500 \mathrm{mg} / \mathrm{kg}$ showed significant antioxidant activity against carbon tetrachloride-induced liver injury in rats. ${ }^{21,22}$

\section{Memory enhancing activity:}

The effects of $T$. populnea bark on cognitive functions in mice was evaluated using Elevated plus-maze and HebbWilliams maze as exteroceptive behavioral models for testing memory. Diazepam, scopolamine, and ageinduced amnesia served as the interoceptive behavioral models. ${ }^{23}$ The ethanol extract of T.populnea (TPE) was administered orally in three doses (100, 200 and 400 $\mathrm{mg} / \mathrm{kg}$ ) for 7 successive days to different groups of young and aged rats. TPE (200 and $400 \mathrm{mg} / \mathrm{kg}$, p.o.) resulted in significant improvement in memory of young and aged rats. TPE also reversed the amnesia induced by scopolamine $(0.4 \mathrm{mg} / \mathrm{kg}$ i.p.) and Diazepam $(1 \mathrm{mg} / \mathrm{kg}$, i.p.) Cholesterol- lowering, Anticholinesterase, Antiinflammatory and Anti oxidant properties of T.populnea may favorably contribute to its memory-enhancement effect. $^{24}$

\section{Hypoglycemic and Antihyperglycemic effects:}

The hypoglycemic and anti hyperglycemic effects of an alcoholic extract of the fruit of T.populnea was investigated in both normal and alloxan-induced diabetes in rabbits. The present study clearly indicated a significant anti-diabetic activity of the fruit of T.populnea and supports the traditional usage of fruits by the Ayurvedic physicians for the control of diabetes.

\section{Anti microbial activity:}

The present study examines the anti bacterial and antifungal activities of T.populnea leaf extracts (hot and cold) using seven solvents (hexane, chloroform, dichloromethane, ethyl acetate, acetone, methanol and water) against human pathogens. Antibacterial and Antifungal activities of crude extracts were determined by disc diffusion method. The highest ant bacterial activity was exhibited by methanol cold extract against Staphylococcus epidermidis $(15 \mathrm{~mm})$ and Bacillus cereus $(14 \mathrm{~mm})$ respectively. Hot hexane extract showed an inhibition zone of $12 \mathrm{~mm}$ against Pseudomonas aeruginosa. Both the cold and hot extracts of all the seven solvents exhibited inhibition zones against Candida albicans. ${ }^{26}$

\section{Wound healing activity:}

The aqueous extract of T.populnea fruit showed significant wound healing activity in the excision wound and incision models in rats following topical and oral administration respectively. ${ }^{27}$

\section{Immunomodulatory:}

The measurement of immunomodulatory property was carried out by delayed type hypersensitivity (DTH), humoral antibody (HA) titer response to SRBC, and cyclophosphamide induced myelo-suppression. Phyto chemical screening suggests the presence of flavonoids, tirterpenoids, proteins, aminoacids, phenolic and steroidal compounds. The immunomodulatory activity of plant may be attributed to its phytochemical constituents. ${ }^{28}$

\section{Cytotoxic activity:}

Eight new sesquiterpenoids named Populene A-H were isolated from dichloromethane extracts of the wood and dark heartwood of T.populnea (Linn.) together with eleven known compounds. Their structures were determined on the basis of spectroscopic analysis. The cytotoxic activity of isolated compound was evaluated against four cancer cell lines: MCF-7, HeLa, HT-29 and KB. Mansonone E and (+)-gossypol showed significant activities. Their anti bacterial properties against Bacillus subtilis, Staphlococcus aureus and Enterococcus faecalis are also presented. ${ }^{29}$

\section{Diuretic activity:}

The study is to investigate the diuretic potential of various extracts of the T.populnea (Linn.) Soland bark such as petroleum ether, ethyl acetate, ethanol, aqueous was assessed in albino rats. The volume of urine, urinary concentration of $\mathrm{Na}+\mathrm{K}+$ and $\mathrm{Cl}$ - ions were the parameters of the study. Furosemide $(100 \mathrm{mg} / \mathrm{kg})$ was 
used as standard. The various extract $(400 \mathrm{mg} / \mathrm{kg})$ has shown significant increase in the volume of urine, urinary concentration of $\mathrm{Na}+\mathrm{K}+$ and $\mathrm{Cl}-$. From the present study it may be concluded that the plant, T.populnea (Linn.) Soland possess significant diuretic activity. $^{30}$

\section{CONCLUSION}

The extensive literature survey revealed that $T$. populnea is a medicinal plant with diverse pharmacological spectrum. The plant shows the presence of many chemical constituents which are responsible for varied pharmacological and medicinal property. The evaluation

\section{REFERENCES}

1. Thespesia populnea Linn: A Review; Panchal Hiteksha, B.Sah mamta; International Journal of pharmacognosy.

2. Mueller-Dombois, D., and F.R. Fosberg, Vegetation of the Tropical Pacific Islands, Springer, New York.1998.

3. Wagner, W.L., D.R. Herbst, and S.H. Sohmer, Manual of the Flowering Plants of Hawaii, rev. ed. University of Hawai'i Press and Bishop Museum Press, Honolulu,1999.

4. Fosberg F.R., Sachet M.H., Thespesia populnea (L.) Solander ex Correa and Thespesia populneoides (Roxburgh) Kosteletsky (Malvaceae), Smithsonian Contributions to Botany, 1972, 7:1-13.

5. Parrotta J.A, Thespesia populnea (L.) Soland. Ex Correa. In: Silvics of Native and Exotic Trees of Puerto Rico and the Caribbean Islands. SO-ITF-SM-76. USDA Forest Service, International Institute of Tropical Forestry, Puerto Rico, 1994.

6. Mendhekar Y, Shinde KR et. al., Pharmacognistic, Phytochemical, Physicochemical and TLC profile studies of leaves of Thespesia populnea sol.ex.correa. (Malvaceae); Seema, European Journal of Pharmaceutical and Medical Research; 4(12):493-498.

7. Datta, S. C.; Murti, V. V. S.; Sharma, N. N.; Seshadri, T. R., Glycosidic components of Thespesia populnea flowers, Indian Journal of Chemistry,1973; 11(5):506-7.

8. Wealth of India, A dictionary of Indian Raw materials and Industrial Products. Council of Scientific and Industrial Research, New Delhi, 1998, 10:223-225.

9. Boonsri S, Karalai C, Ponglimanont, C, Chantrapromma; S, Cytotoxic and Antibacterial Sesquiterpenes from Thespesia populnea, Journal of Natural products; 2008, 71:1173-1177.

10. Neelakantan S., Rajagopalan V., Raman P. V., Thespesone and thespone, two new mansonone of heartwood of Thespesia populnea ex Corr. (Fam. Malvaceae), Indian Journal of Chemistry, Section B: Organic Chemistry Including Medicinal Chemistry, 1983, 22B(1):95-6.

11. Isolated mansonone, 7-hydroxy-2,3,5,6-tetrahydro-3,6,9trimethylnaphtho[1,8-b,c]pyran-4,8-dione, and mansonones D, $\mathrm{E}$ and $\mathrm{F}$ from the heartwood of Thespesia populnea; Mibrodt et al., 1998.

12. Puckhaber L, Stipanovic R, Thespesenone and Dehydrooxoperezinone-6-methyl Ether, New Sesquiterpene Quinones from Thespesia populnea, Journal of Natural product.2004, 67:1571-1573.

13. Vasudevan M, Gunnam K, Parle M, Antinociceptive and antiinflammatory effects of Thespesia populnea bark extract, Journal of Ethnopharmacology; 2007, 109:264-270.

14. Zhang d; Zhang Si; Wu J, Chemical constituents of the bark of Thespesia populnea, 2007, 18(9):2156-2157.

15. Thespesia populnea - a rich source of $\beta$-sitosterol and lupeol; Goyal, M. M.; Rani, KumKum; ActaCiencia Indica, Chemistry; 1985, 11(3):163-164.

16. Shah A, Alagawadi K, Antiinflammatory, analgesic, antipyretic activity of Thespesia populnea seed extracts ant its fraction in animal models, Journal of Ethnopharmacology; 2011; 37:1504-1509. needs to be carried out on T. populnea in order to uses and formulation of the plant in their practical clinical applications, which can be used for the welfare of the mankind.

\section{ACKNOWLEDGEMENT}

The authors are thankful to the Management and Principal of Gland Institute of Pharmaceutical Sciences for their kind support. The authors are also grateful to the authors/editors of all those articles, journals and books from where the matter for this article has been reviewed and discussed.

17. Viswanatha G, Hanumanthappa H, Rangappa S, Antidiarrhoeal effect of fractions from stem bark of Thespesia populnea in rodents, Pacific Journal of Tropical Medicine; 2011; 4:451-456.

18. Yuvaraj P, Subramaniam A, Hepatoprotective property of Thespesia populnea against carbon tetrachloride induced liver damage in rats, J Basic Clin Physiol Pharmacol, 2009; 20:16977.

19. Ilavarasan, R.; Vasudevan, M., Anbazhagan, S.; Venkataraman, S., Sridhar S. K, Hepatoprotective activity of Thespesia populnea bark extracts against carbon tetrachlorideinduced liver toxicity in rats, Natural Product Sciences, 2003, 9(2):83-86.

20. Ghosh K, Bhattacharya T, Preliminary study on the antiimplantation activity of compounds from the extracts of seeds of Thespesia populnea, Indian journal of Pharmacology; 2004, 36:288-291.

21. Iiavarasan R, Vasudevan M, Anbazhagan S, Antioxidant activity of Thespesia populnea bark extracts against carbon tetrachloride-induced liver injury in rats, Journal of Ethnopharmacology; 2009, 87:227-230.

22. Sahu A, Shivkumar H, Rao NR, Jayakumar Swamy B. H. M. and Prakash, T., Anti-oxidant activity of flower extracts of Thespesia populnea, Journal of Pharmacy and Chemistry; 2007, 1(1):18-21.

23. Vasudevan M, Parle M, Memory enhancing activity of Thespesia populnea in rats, Journal of pharmaceutical biology; 45(4):267-273.

24. Vasudevan M, Parle M, Pharmacological actions of Thespesia populnea relevant to Alzheimer's disease, Phytomedicine; 2006, 13:677-687.

25. Satyanarayana T, Sarita, Balaji M, Murthy K, Antihyperglycemic and Hypoglycemic effect of Thespesia populnea fruit in normal and alloxan induced diabetes in rabbits Saudi Pharmaceutical journal; 2004; 12:2-3.

26. Pratap chandran R, Manju S, Vysakshi M.V. , Shaji P.K., Achuthan Nair G, Antibacterial and Anti fungal activities of Thespesia populnea leaf extracts against human pathogens, International journal of pharma tech research; 6:290-297.

27. Nagappa A, Cheriyan B, Wound healing activity of the aqueous extract of Thespesia populnea, Fitoterapia; 2001; 72:503-506.

28. Gaikwad Switi B., Krishna Mohan G., Immunomodulatory activity of methanolic extract of Thespesia populnea leaves in wistar albino rats, Asian Journal of Pharmaceutical and Clinical Research; 2011, 4(4):99-101.

29. Kumar S, Bajwa BS, SinghK, Anti inflammatory activity of Herbal plants: A review, International journal of advances in pharmacy, biology and chemistry; 2(2).

30. Parthasarathy R, Illavarasan R, A study on preliminary phytochemical and diuretic activity of bark of Thespesia populnea, International Journal of pharma science and research; 1(2):72-77. 